\title{
Platinized Titanium Anode for Chlor-Alkali Electrolysis
}

\author{
Kiyoshi AOKI
}

Ajinomoto Co., Inc. Takara-cho, Chuo-ku, Tokyo

Reported at the 129th Meeting of the Electrochemical Society in Cleveland, Ohio, May 3, 1966.

Received Aug. 1, 1966

\begin{abstract}
The preparation of a platinized titanium anode for the chlorine cell was studied. Platinum was electrodeposited on a titanium plate whose surface was microetched in alkali halide molten salt. This electrode showed superior characteristics such as low anodic potential, good adhesion, and small consumption of platinum compared with the usual platinized titanium anode. The Pt-Ti anode of the "sawteeth cross section" was conceived in order to reduce the anodic potential in a practical amalgam cell, and it could be compared with a graphite anode. The cell using the new anode could be operated for a long time without any trouble:
\end{abstract}

The platinized titanium anode is considered to be as durable in chlorine cell as graphite is, but some problems such as adhesion, overvoltage and consumption of platinum exist with it. In order to reduce these problems many tests have been carried out. Immersion of the base metal in alkali halide molten salts before plating brought good results. ${ }^{1)}$ Preparation of the anode and some examinations performed in the chlorine cell are described below.

\section{Preparation of Sample Anode}

A titanium plate was immersed in al$\mathrm{kali}$ halide molten salts such as $\mathrm{NaCl}$, $\mathrm{KCl}$, and others to obtain a micro-etched surface. The formation of pyrosol consisting of fine particles of titanium dissolved in the fused salts is very important. After withdrawal from the molten salt bath, the surface of the titanium was well rinsed with water, and washed with a hot solution of $40 \%$ phosphoric acid or other inorganic acid solutions in order to remove fine titanium particles adhering to it. The dissolution of the surface of about $10 \mathrm{mg} / \mathrm{cm}^{2}$ was necessary to obtain the best results in the electroplating platinum from the usual solution, whose characteristics are as follows:

Solution:

Chloroplatinic acid

$$
\left(\mathrm{H}_{2} \mathrm{PtCl}_{6} .6 \mathrm{H}_{2} \mathrm{O}\right)
$$

Mono ammonium phosphate

$45 \mathrm{~g} / \mathrm{l}$

Diammonium phosphate

$\mathrm{pH} \quad$ 5-7

$240 \mathrm{~g} / \mathrm{l}$

Current density

$$
0.3 \mathrm{~A} / \mathrm{dm}^{2}
$$

Temperature about $100{ }^{\circ} \mathrm{C}$

The removal of the oxide film on the surface of the titanium before pretreatment by molter salts, and the use of a steel or nickel vessel for containing the molten salts were recommended; moreover, the addition of graphite powder into the molten salts or the use of a graphite vessel resulted in the $\mathrm{Ti}$ dissolution rate being several times 
the normal one. Also two other plating solution consisting of either $\mathrm{K}_{2} \mathrm{Pt}\left(\mathrm{NO}_{2}\right)_{2} \mathrm{SO}_{4}$ or $\mathrm{Pt}\left(\mathrm{NH}_{3}\right)_{2}\left(\mathrm{NO}_{2}\right)_{2}$ were examined.

\section{Adhesion Test}

A plated disk of $3 \mathrm{~cm}$ diameter and $0.3 \mathrm{~mm}$ thick was prepared. The specimen was held in a vise and bent in its middle $90^{\circ}$ back and forth until peeling of the plating or breaking of base metal occurred.

There are many deep crevices with micro-etchings on the surface of titanium treated in alkali halide molten salts, and the electrodeposition of platinum took place in these crevices thus yielding good adhesion as shown in Fig. $1 a_{2}$ whereas the samples treated in $85 \%$ phosphoric acid and $35 \% \mathrm{HCl}$ have rather flat surfaces, and the platinum layer is easily peeled continuously (see Fig. $1 \mathrm{c}$ and 1 b respectively). According to the adhesion test,

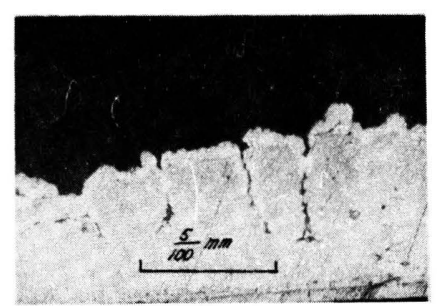

Fig. la Section of platinized titanium anode pretreated with fused salt bath consisting of $\mathrm{NaCl}$ and $\mathrm{KCl}$. $\mathrm{Pt}$ deposit is $10.0 \mathrm{mg} / \mathrm{cm}^{2}$.

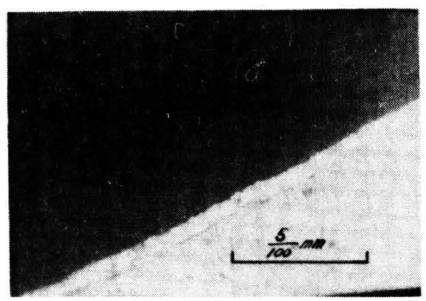

Fig. 1b Section of platinized titanium anode pretreated with $35 \% \mathrm{HCl}$. Pt deposit is $11.2 \mathrm{mg} / \mathrm{cm}^{2}$.

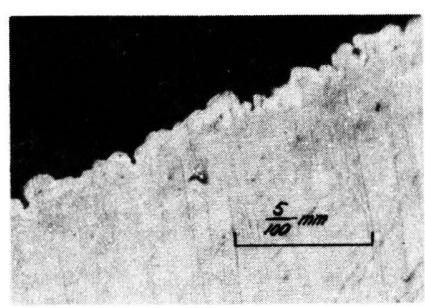

Fig. 1c Section of $\mathrm{Pt}-\mathrm{Ti}$ anode pretreated with $85 \% \mathrm{H}_{3} \mathrm{PO}_{4}$. Pt deposit is $10.5 \mathrm{mg} / \mathrm{cm}^{2}$.

described above, platinum plating pretreated with alkali halide molten salts did not peel until breaking occurred after 9 10 times of bending, but the samples pretreated with acid solutions were peeled with only $1-3$ bendings. A good coherent plating as thick as $9.3 \mathrm{microns}$ or $20 \mathrm{mg} / \mathrm{cm}^{2}$ was mantained on titanium treated with molten salts.

\section{Laboratory Test}

A laboratory cell used is shown in Fig. 2. The anode is of $30 \mathrm{~mm}$ diameter and 1

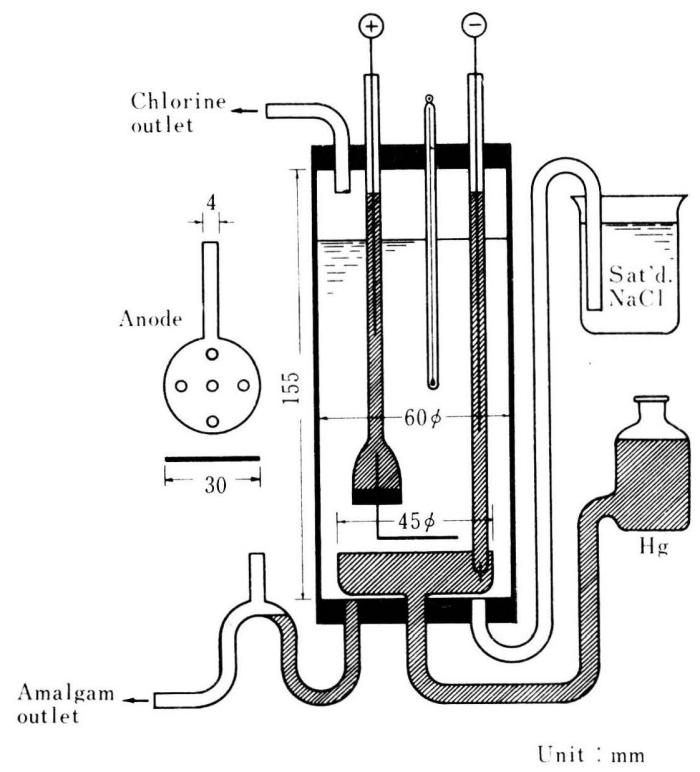

Fig. 2 Laboratory chlorine cell of mercury type. 
$\mathrm{mm}$ thick, and has five holes of $3 \mathrm{~mm}$ diameter. The current lead is connected to the edge of the disk. This anode was set in a cell $5 \mathrm{~mm}$ above the surface of an amalgam cathode. The anode in Table 1 was plain, but the back of the anode reported

Table 1 Cell Voltage in Laboratory Cell with Platinized Titanium Anodes

\begin{tabular}{|c|c|c|c|c|c|c|c|}
\hline \multirow[t]{2}{*}{ Pretreatment } & \multirow{2}{*}{$\begin{array}{l}\text { Weight loss of } \mathrm{Ti} \text { in Pre- } \\
\text { treatment }\left(\mathrm{mg} / \mathrm{cm}^{2}\right)\end{array}$} & \multirow{2}{*}{$\begin{array}{l}\text { Pt deposited } \\
\left(\mathrm{mg} / \mathrm{cm}^{2}\right)\end{array}$} & \multicolumn{5}{|c|}{ Voltage at current density of } \\
\hline & & & $\begin{array}{c}20 \\
\mathrm{~A} / \mathrm{dm}^{2}\end{array}$ & $\begin{array}{c}40 \\
A / \mathrm{dm}^{2}\end{array}$ & $\begin{array}{c}60 \\
\mathrm{~A} / \mathrm{dm}^{2}\end{array}$ & $\begin{array}{c}80 \\
\mathrm{~A} / \mathrm{dm}^{2}\end{array}$ & $\begin{array}{l}100 \\
\mathrm{~A} / \mathrm{dm}^{2}\end{array}$ \\
\hline $85 \% \mathrm{H}_{3} \mathrm{PO}_{4}$ (boiling) & 24.1 & 4.9 & 3.78 & 4.01 & 4.32 & 4.65 & 4.85 \\
\hline $35 \% \mathrm{HCl}$ (boiling) & 11.9 & 6.6 & 3.70 & 3.97 & 4.26 & 4.51 & 4.80 \\
\hline $\mathrm{NaCl} \quad$ (fused) & 15.7 & 4.6 & 3.45 & 3.70 & 4.00 & 4.30 & 4.55 \\
\hline $\begin{array}{c}\mathrm{NaCl}(50 \%)+\mathrm{KCl}(50 \%) \\
\text { (fused) }\end{array}$ & 11.3 & 4.8 & 3.45 & 3.72 & 3.95 & 4.30 & 4.55 \\
\hline
\end{tabular}

Table 2 Cell Voltage in Laboratory Cell, Pt-Ti Anode and Graphite Anode

\begin{tabular}{l|c|c|c|c|c}
\hline \multirow{2}{*}{ Materials } & \multicolumn{5}{|c}{ Voltage at current density of } \\
\cline { 2 - 6 } & $\begin{array}{c}20 \\
\mathrm{~A} / \mathrm{dm}^{2}\end{array}$ & $\begin{array}{c}40 \\
\mathrm{~A} / \mathrm{dm}^{2}\end{array}$ & $\begin{array}{c}60 \\
\mathrm{~A} / \mathrm{dm}^{2}\end{array}$ & $\begin{array}{c}80 \\
\mathrm{~A} / \mathrm{dm}^{2}\end{array}$ & $\begin{array}{c}100 \\
\mathrm{~A} / \mathrm{dm}^{2}\end{array}$ \\
\hline $\mathrm{Pt}-\mathrm{Ti}$ & 3.65 & 3.97 & 4.29 & 4.65 & 5.05 \\
Graphite & 3.50 & 3.78 & 4.08 & 4.40 & 4.75 \\
\hline
\end{tabular}

in Table 2 was insulated with Lucite resin. The mercury cathode had a $15.9 \mathrm{~cm}^{2}$ area, and its surface was always renewed. A saturated $\mathrm{NaCl}$ solution of about $\mathrm{pH} 3$ was electrolyzed under the operating temperature of $60^{\circ} \mathrm{C}$. The cell voltages of the laboratory cell with various anode were measured, and the results obtained are shown in Table 1 . It is noticed that the anode treated by molten salts shows cell voltages, $0.2-0.3 \mathrm{~V}$ lower than the others, and it might be due to its lower overvoltage over a large surface area.

A comparison with a graphite anode was also made. In this test, the size of the graphite sample was the same as that of the Ti, except for its thickness which was $9 \mathrm{~mm}$. Unfavorable results regarding cell voltages for the platinized titanium anode (pretreated by the molten salt) were obtained as shown in Table 2: 0.2 -
$0.3 \mathrm{~V}$ higher than graphite. The difference between Table 1 and 2 for the platinized titanium anode is due to differences of surface area, as described above.

Small anodes shown in Fig. 2 were placed in the end box of an industrial mercury cell, and polarized at $55-75 \mathrm{~A} / \mathrm{dm}^{2}$ current density. The consumption of platinum was about $3 \mathrm{mg} / \mathrm{kAh}$ and was almost independent of the thickness of the plating in the range of $5-20 \mathrm{mg} / \mathrm{cm}^{2}$ as shown in Fig. 3. The consumption of $\mathrm{Pt}$ on a

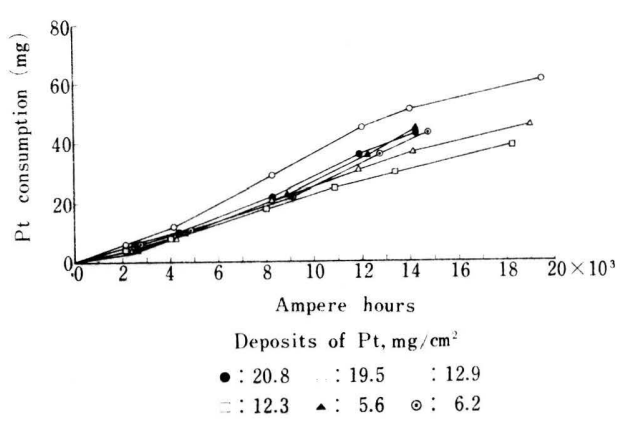

Fig. 3 Consumption of platinum vs. ampere hours of various deposits.

base treated with fused salts was considerably smaller than with others i.e., about a 1.3 times longer life than that of a plat- 
ed anode treated with an acidic solution as shown in Fig. 4.

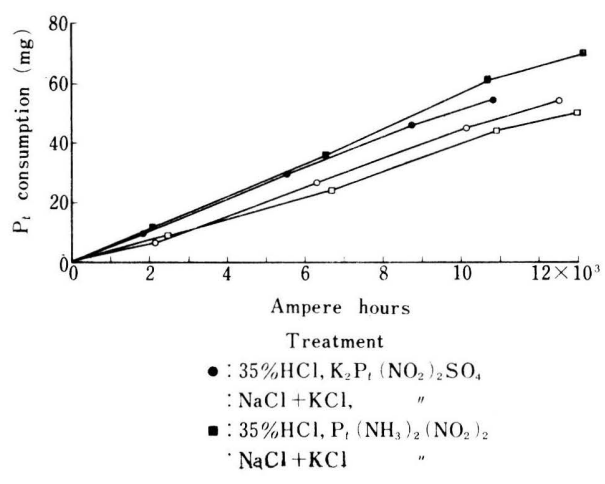

Fig. 4 Consumption of Platinum on various titanium surfaces.

The effect of short circuit on the loss of platinum was examined. Platinized titanium anode touched down to the surface of amalgam cathode at a current density of $10 \mathrm{~A} / \mathrm{dm}^{2}$, then it was polarized to $40-60 \mathrm{~A} / \mathrm{dm}^{2}$. This was done 13 times in 3940 hours of electrolysis, and the consumption was rated to be about $4 \mathrm{mg} / \mathrm{KAh}$, which is about $30 \%$ more than during normal operation.

\section{Test in an Industrial Cell}

Large platinized titanium anodes shown in Fig. 5 were tested in an industrial mer-
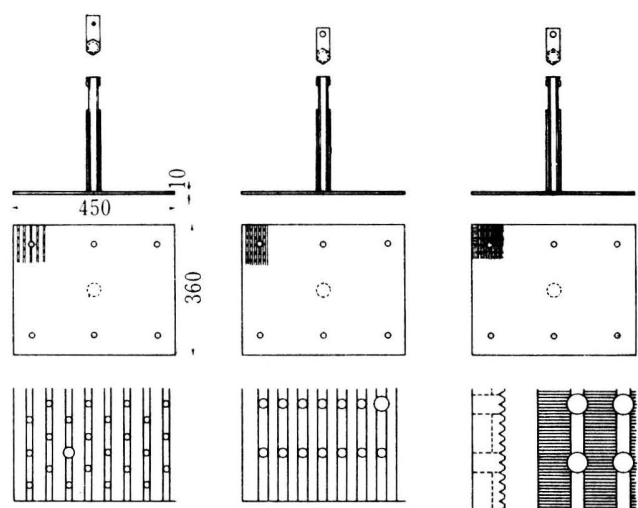

$-45-5$

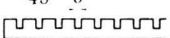

(A)
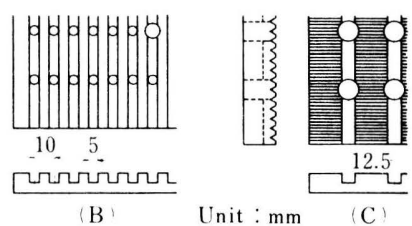

Fig. 5 Pt-Ti anodes for 12,000-ampere mercury cell. cury cell of $12 \mathrm{kA}$, which is normally operated with 21 graphite anodes $360 \mathrm{~mm}$ wide, $450 \mathrm{~mm}$ long and $75 \mathrm{~mm}$ thick at 35.3 and $32.6 \mathrm{~A} / \mathrm{dm}^{2}$ current densities of the anode and cathode, respectively. The $\mathrm{pH}$ of the feed brine was about 11 and of the return flow was about 4 . The temperature was $70^{\circ} \mathrm{C}$.

Two platinized titanium anodes, Types $A$ and $B$ in Fig. 5, had similar profiles but of different dimensions, and Type C had a "saw-teeth" profile. The weight of the platinum plating on an anode $360 \mathrm{~mm}$ wide, $450 \mathrm{~mm}$ long, and $10 \mathrm{~mm}$ thick was $5-13 \mathrm{~g}$, or an average of $10.4 \mathrm{~g}$ per anode.

The ohmic resistance from the top of the current lead to the surface of the metal anode was $80 \mu \Omega$, which is about half of the $150 \mu \Omega$ of graphite anodes.

Some metal anodes were placed : among the graphite anodes and compared with them at the preliminary examination, and then, all graphite anodes were replaced with 5 of Type B and 16 of Type C. One anode of Type $B$ was arranged after every 3 of Type C. The cell was operated for 40 days under the conditions shown in Table 3. No significant differences of hydrogen

Table 3 Results in Operation of 12,000-ampere Mercury Cell

\begin{tabular}{|c|c|c|}
\hline \multicolumn{3}{|l|}{ Operating conditions } \\
\hline Current, kA & \multicolumn{2}{|l|}{12} \\
\hline Anode current density, $\mathrm{A} / \mathrm{dm}^{2}$ & \multicolumn{2}{|l|}{35.2} \\
\hline \multirow[t]{2}{*}{ Cathode current density, $\mathrm{A} / \mathrm{dm}^{2}$} & \multicolumn{2}{|l|}{32.6} \\
\hline & \multicolumn{2}{|c|}{ Mean value $\sigma$} \\
\hline \multicolumn{3}{|l|}{ Temperavture of brine: } \\
\hline Inlet, ${ }^{\circ} \mathrm{C}$ & 56.4 & 2.92 \\
\hline Outlet, ${ }^{\circ} \mathrm{C}$ & 72.6 & 3.86 \\
\hline \multicolumn{3}{|l|}{ Concentration of brine: } \\
\hline Inlet, $\mathrm{g} / l$ & 304.1 & 4.26 \\
\hline Outlet, $\mathrm{g} / l$ & 215.6 & 10.25 \\
\hline \multicolumn{3}{|l|}{ pH of brine: } \\
\hline Inlet & 11.37 & 0.295 \\
\hline Outlet & 4.04 & 0.994 \\
\hline Concentration of chlorine, $\%$ & 97.8 & 0.43 \\
\hline Hydrogen content, $\%$ & 0.63 & 0.008 \\
\hline Current efficiency, $\%$ & 94.5 & 1.14 \\
\hline
\end{tabular}


content in the anode gas, and in the current efficiency of the metal anode cell compared with those of the graphite anode cell were observed.

Type A anode was employed with graphite in a $12 \mathrm{kA}$ cell. A metal anode of Type A was arranged between two graphite anodes, and the electric current passing through the metal and graphite anode was determined under equal terminal voltages. The results obtained are shown in Fig. 6.

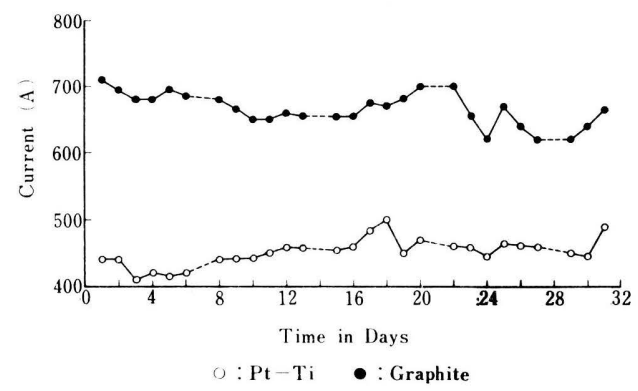

Fig. 6 Current passing through platinized titanium anode and graphite anodes of the Type $A$ in Fig. 5.

The considerably small current passing through the metal anode compared with the mean value of the two graphite anodes was due to its high chlorine overvoltage. One possibility for increasing the current or reducing the overvoltage on the metal anode is the use of the "saw-teeth crosssection" anode shown in Fig. 5, Type C. It was examined by the same manner as described above, and showed characteristics competitive with those of the graphite anode as shown in Fig. 7.

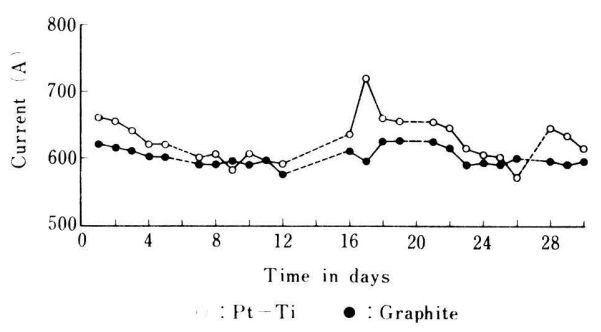

Fig. 7 Current passing through platinized titanium anode of "saw-teeth cross section" and graphite anode.
Because of complicated reasons, however, there is no significant difference between the currents passing through the metal anodes of Type $B$ and $C$. The current distribution through 21 metal anodes in a $12 \mathrm{kA}$ cell is shown in Fig. 8. Num-

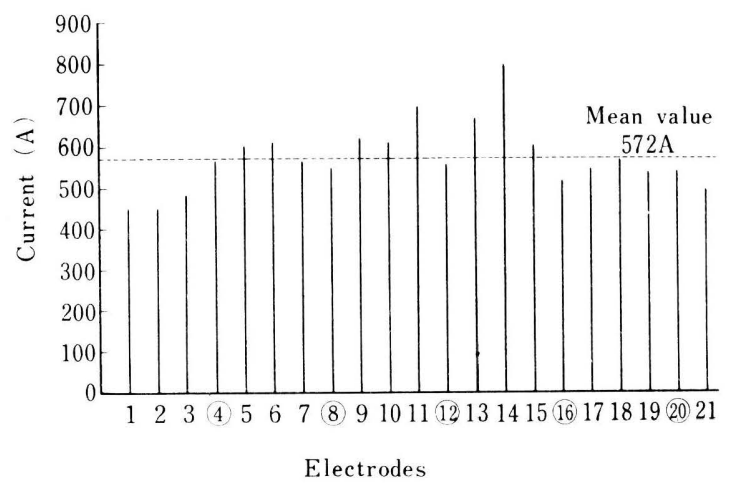

Fig. 8 Current distribution of $\mathrm{Pt}_{\mathrm{t}} \mathrm{T}_{1}$ anodes in 12,000-ampere mercury cell.

Numbers in circles show the anode, Type B.

bers inside circles indicate a Type B anode, and the others correspond to Type C.

The terminal voltage of the metal anode cell was observed for 40 days after it was stabilized through the preliminary operation of about 20 days under the conditions of practical operation, and it was referred to the graphite anode cell, which was under continuous operation for 50 days after the renewal of all graphite anodes. Terminal voltages of the two cells were almost the same as shown in Fig. 9, while the voltage

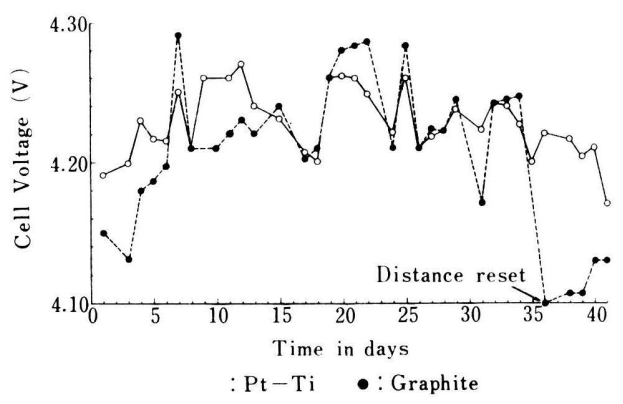

Fig. 9 Comparison of cell voltages between $\mathrm{P}_{\mathrm{t}} \mathrm{Ti}$ and graphite in 12,000-ampere mercury cell. 
of the graphite anode cell became smaller than the other one by controlling the gap between the electrodes. The life of a graphite anode $75 \mathrm{~mm}$ thick is about 240 days under $35 \mathrm{~A} / \mathrm{dm}^{2}$, but the cell voltage increase up to $4.3 \mathrm{~V}$ at the end of the period. Thus, it seems that the power consumption of the metal anode cell is almost equal to the graphite anode cell for a long run.

\section{Conclusion}

The preparation of platinized titanium anode for mercury type chlorine cell was studied, and the importance of the pretreatment of the base metal to be electrodeposited with platinum to obtain suitable results for the anode, such as a low overvoltage, good adhesion, durability, and other properties under the operating conditions of a chlorine cell, was demonstrated.

The treatment of the titanium surface by means of immersion in alkali halide molten salts such as $\mathrm{NaCl}, \mathrm{KCl}$ and their mixtures gave good results. Titanium dissolves in the molten salt as pyrosol and microetched surface with deep crevices is obtained. For the preparation of durable anode, a surface dissolution of titanium of about $10 \mathrm{mg} / \mathrm{cm}^{2}$ is necessary.

$\mathrm{Platinum}$ is electrodeposited from the usual bath after a complete rinse of the pre-treated titanium with water and acid solution. Since the crevices on the titanium surface are filled with platinum deposits, good adhesion can be obtained. These samples were used in the various tests, but two specimens pre-treated with $85 \%$ hot phosphoric acid and $35 \%$ hydrochloric acid, respectively, were al so used for reference.

The adherence of the new platinized titanium sample was confirmed by bendtest, that is, platinum did not peel until breakage of the base metal occurred after
9-10 bendings, whereas the platinum plated on other samples pre-treated with acids was removed with only $1-3$ bendings.

The anode potential on the new material was about $0.3 \mathrm{~V}$ lower than that on other metal anodes pre-treated with acids at $60 \mathrm{~A} / \mathrm{dm}^{2}$ current density, but it is still $0.2 \mathrm{~V}$ higher than that of graphite. In order to decrease the anode potential on the new metal, an anode of "saw-teeth cross section" was prepared, and employed in an industrial mercury cell. The cell voltage measured could be compared with those of the usual graphite anode cell. The cell was operated at 35.3 and $32.6 \mathrm{~A} / \mathrm{dm}^{2}$ of anode and cathode current densities, respectively. The cell voltages of two electrolyzers using metal and graphite anode showed almost the same values, but, of course, the graphite anode assembly showed very low voltages immediately after the control of the distance between electrodes.

The consumption of platinum for a long run in a practical mercury cell was on the average $3 \mathrm{mg} / \mathrm{kAh}$ at $55-75 \mathrm{~A} / \mathrm{dm}^{2}$ current density. The most important notice for use of the metal anode in a mercury cell is to avoid contact with the amalgam cathode, from the view-points of the consumption of platinum, loss of active surface and other troubles. Very little contamination or drifts in the returning brine and amalgam from the cell using a metal anode was observed, and the cell could be operated for a long time without any trouble such as hydrogen formation and the decrease of current efficiency.

\section{Acknowledgement}

The author would like to express his acknowledgement to Dr. F. Hine of Kyoto University, for his helpful comments concerning the manuscript, and to S. Honda, T. Kawashima and $M$. Watanabe as well as other members of the laboratory staff for their assistance in carrying out the experimental work. 
Literature:

(1) Japan 459, 468, Nov. 2, 1965, Appl. Mar.
29, (1963); Brit. 998, 709, Nov. 10, 1965,

Appl. Mar. 26, (1964); Fr. 1,386, 198, Dec. 7, 1964, Appl. Mar. 31, (1964).

\title{
The Effect of Fluoride Ion on Corrosion of
} Aluminum Oxide Film in Citrate Solution*

\author{
Masayoshi KATOH \\ Department of Applied Chemistry, Faculty of Science, \\ Tokyo College of Science, Shinjuku-ku, Tokyo
}

Received Oct. 21, 1966

In order to examine the mechanism of the accelerating effect of fluoride ion on corrosion of aluminum in a citrate solution of which $\mathrm{pH}$ is 3.5 , corrosion behaviours of aluminum oxide film in the related solutions have been studied.

The oxide film was prepared by anodizing $99.99 \%$ aluminum foil in sulphuric acid solution followed by isolating the film in mercuric chloride solution.

The film was scarecely attacked by citrate solution only, while the addition of a small amount of fluoride ion accelerated the corrosion considerably and the film almost disappeared. In a solution containing fluoride ion only, on the contrary, weight of the film increased although it collapsed into a fine insoluble powder.

From these results together with the fact reported in the previous paper that aluminum fluoride was detected on the surface after corrosion in sodium fluoride solution by X-ray diffraction analysis, it was concluded that the aluminum oxide film could be attacked by fluoride ion to form insoluble and more weighty aluminum fluoride, which in turn was soluble in the citrate solution at a relatively high rate. .

The present study can also suggest that reagents which can not by themselves attack aluminum in spite of their ability to form soluble chelates or salts, will be corrosive agents when small amounts of fluoride ion is added, and the aluminum fluoride replacing the surface oxide film is soluble in the reagents at high rates. 